\title{
EXISTENTIALISM BY SOREN AABYE KIERKEGAARD: INDIANA IN INDIANA JONES AND THE LAST CRUSADE AS A REPRESENTATION OF AN “AUTHENTIC" HUMAN BEING
}

\author{
Chintia Asmiliasari
}

\begin{abstract}
Abstrak
Eksistensialisme Soren Aabye Kierkegaard merupakan kajian filsafat yang menitikberatkan pada konsep eksistensi dari seorang individu sebagai makhluk yang otentik. Eksistensialisme setiap individu hanya dapat tercapai melalui keberanian dan keyakinan seorang individu dalam membuat keputusan secara bertanggung jawab dan berkomitmen atas keputusan tersebut. Keputusan yang dibuat oleh setiap individu yang eksis harus didasari oleh subjektifitas kebenaran yang diyakininya tanpa terpengaruh oleh realitas apa adanya atau kebenaran objektif yang bersifat kolektif. Kebenaran subjektif inilah yang kelak menuntun setiap individu dalam menemukan kebenaran absolut ditengah kecemasan atas ketidakpastian dari setiap keputusan yang diambil. Dengan totalitas keyakinan yang dimiliki oleh setiap individu dalam membuat keputusan dan menjalankannya dengan komitmen penuh, akhirnya, membawa seorang individu kepada eksistensi dirinya sebagai seseorang yang otentik.

Indiana dalam Indiana Jones and the Last Crusade merepresentasikan seorang individu dengan kualitas esksistensialisme Soren Aabye Kierkegaard. Dimulai dari keterkepungannya oleh kebenaran objektif seorang arkeolog, kecemasannya dalam menentukan pilihan dan membuat sebuah keputusan hingga membawanya pada sebuah kebenaran subjektif dalam menemukan kebenaran absolut atas dasar kediriannya dan mejadi seorang individu yang eksis.
\end{abstract}

\section{Kata kunci}

Eksistensialisme, Kebenaran Objektif, Kebenaran Subjektif, Keputusasaan (Despair), Estetis, Etis, Religius, Komitmen, Leap of Faith, Knight of Faith.

\begin{abstract}
Existentialism of Soren Aabye Kierkegaard is a study focusing on the individual existence as an authentic creature. Existentialism can only be achieved by an individual's boldness and belief to commit responsibly to a decision he has made. The decision made by each individual should be based on his subjective truth and should not be influenced by the collective truth called the objective truth. The subjective truth will later lead each individual to his way finding an absolute truth, although despair and uncertainty haunt every decision he has made. A totality of believing in making decision and holding the commitment into it will finally bring an individual to the existence of himself as the most authentic creature. Indiana in Indiana Jones and the Last Crusade represents an individual with a quality of Soren Aabye Kierkegaard's Existentialism concept. It is begun from Indiana's imprisonment in his objective truth as an archeologist, his despair at making a choice and decision, in which finally turned him into someone who finds an absolute truth based on his subjective truth. At last, his finding has led him into an existence and authentic individual.
\end{abstract}

\section{Keywords}

Existentialism, Objective Truth, Subjective Truth, Despair, Aesthetic, Ethic, Religious, Commitment, Leap of Faith, Knight of Faith. 


\section{INTRODUCTION}

This paper aims to give an understanding of existentialist thought developed by Soren Aabye Kierkegaard, and how this thought is applied to the character Indiana in Indiana Jones and the Last Crusade film as an instrument of the research. There are three important elements of existentialism that will be covered in this study. First, the subjective truth which is built by human's consciousness, helps Indiana to abandon his objectivity as an archeologist whose responsibility is to find facts rather than the truth. The second element is despair. According to Kierkegaard, in a process of finding subjectivity, human beings will experience some kind of despairs. In the movie, experiencing despairs determines Indiana's decision on whether he will always believe in his objectivity as an archeologist or he will believe in his subjectivity as "Indiana." Finally, becoming 'exist' and 'authentic' are the main purposes of existentialism which can only be achieved through experiencing the three stages of becoming 'exist' based on Kierkegaard's theory.

According to Kierkegaard, human beings become 'exist' and 'authentic' when they have already had a faith that is built by their own subjectivity and surrender their lives to The Absurd (God). Furthermore, there are three stages that should be passed to become an 'exist' and 'authentic' human being. The first stage is aesthetic. In this stage, human beings do not have consciousness of what they have done or what they are going to do, so they tend to do something without considering the possibilities which may occur. In this stage, the aim of human being is only to fulfill his/her libido. The next stage is ethic. In this stage, the consciousness has been built. Human beings begin to realize the existence of norms and rules in society. Hence, they start to consider what they have done and what they are going to do based on the established rules and norms. The last stage will be religious. In this stage, human beings will surrender themselves to God, and they will do something based on their faith and what they believe in. Based on the explanations, those three elements of existentialism proposed by Kierkegaard will be used in analyzing Indiana as a representative of an 'exist' individual in a real life.

Referring to Paul Roubiczek in Existentialism for and against, existentialism is a reaction against the Age of Reason. "The need for that kind of philosophy which, to a certain extent, comes into being in Existentialism can be best understood as a reaction against the Age of Reason" (Roubiczek, 1964, 1). In this age, most philosophers assumed everything happened by reason or in other words, the absoluteness is the reason. However, Roubiczek opposed this statement by stating that believing in absoluteness is irrational because the power of reason has limitations that cannot define transcendental or metaphysical things such as uncertain future or even God. Therefore, existentialists come up with their thought against the Age of Reason. Moreover, it is supported by David E. Cooper in Existentialism ( $2^{\text {nd }}$ edition) who stated that existentialists not only reject representational theory, but also the whole idea about the isolated subject caught in the "egocentric predicament" concept. According to Thomas Hidya Tjaya in Kierkegaard dan 
pergulatan menjadi diri sendiri, both representational theory knowledge and "egocentric predicament" are objectives that restrict human beings in finding their own subjectivity. As a result, the life of human beings is subjected to follow what rationalists have set as the truth and nobody can deny this because the aim of rationalists is to generalize human beings. Hence, Tjaya stated that humans' subjectivity is abandoned by rationalists so that it makes human beings no longer feel that they 'exist'.

Opposing the previous statements about the absoluteness of reason, he said that it is unacceptable because human beings are not limitless, and there will come a time when human beings are no longer able to define and reason a particular situation in their lives. However, they can go through their limitation by surrendering their lives to The Limitless (God) and keeping holding on what they believe in. In other words, human beings need their faith to stay 'alive'. To illustrate, in the last scene of Indiana Jones and the Last Crusade, Indiana has to pass three challenges posed by the Holy Grail, and one of them is called 'the Path of God'. In this scene, Indiana has to cross a canyon without any bridge at all. Logically speaking, people would not pass the canyon since it does not have a bridge, or they would die. However, by his faith, he surrenders his life to The Limitless (God) and puts his feet on the path that does not have the bridge. Surprisingly, there is an unseen bridge connected the canyons. This scene shows that there is something that cannot be defined by logical reason, something beyond our self that could only be achieved by believing and committing to our faith and doing something for what we believe. Here the role of existentialists occurs to give enlightenment, to show that humans' logical thinking does not last long. Therefore, the absoluteness is not reason but our faith to The Limitless or The Absoluteness.

\section{SUBJECTIVETRUTH AND THREE STAGES OF EXISTENTIALISM}

Existentialism of Soren Aabye Kierkegaard emphasizes on how human beings deal with their freedom of choices to find the absolute truth. In this case, the absolute truth lies on every individual's subjectivity called subjective truth. In subjectivity, individuals will always relate themselves to an inward truth, which is reflected subjectively (Kierkegaard, 1992:199). Kierkegaard in Concluding Unscientific Postscript illustrates this situation by comparing subjectivity with objectivity. According to Kierkegaard, individuals in their objectivity will always relate themselves to something which is considered a conventional truth; while in their subjectivity, individuals will only relate themselves to the truth that they believe as true even though what they believe can be considered as untruth (Kierkegaard, 1992:199). The untruth is something which goes beyond humans' common sense. It is absurd, uncertain and unpredictable. For example, our life in the future is a mystery, and no one can predict what is going to happen. However, people who believe in their objectivity may think that the untruth is not necessarily the real truth because the truth for them is a certainty; something that is predictable. Kierkegaard affirms in 
his book that, "objectively the emphasis is on what is said; subjectively the emphasis is on how it is said" (Kierkegaard, 1992, p.202). Nevertheless, to be subjective does not mean to be self-righteous and selfish because there will always be a risk for every decision. Hence, having a faithful commitment is the most important thing in building up subjectivity. Later, subjective truth plays an important role in the journey through to pass the three stages of existentialism; aesthetic, ethical and religious.

Aesthetic is the very basic stage of existentialism which requires human beings to experience euphoria in their life. In this stage, human avoids taking any commitments, whether personal, social, or official (Kenny, 2006:327). In other words, human beings are free to do anything without considering the moral values of society. Their goal is only to get what they want and fulfill their libido (desire). "The aesthetic person thinks of his existence as one of freedom: but in fact it is extremely limited" (Kenny, 2006:328). An aesthetic person will never realize that he/she is desperately experiencing despair. However, an aesthetic person can level up his/her existence by committing him/herself to the next stage called ethic. In the ethical stage, human beings begin to take part in society by committing their life to the established moral values whether it is personally, socially or officially. An ethical person will always make a decision based on an absolute moral standard in society to deepen his/her meaning of life (Edwards, 1974:473). Nevertheless, an ethical person cannot be categorized as existing or being authentic individual because there is still a sense of objectivity in moral values that restrict human beings to build up their subjectivity. Thus, to meet subjectivity, each individual should detach his/her life from the demand of the moral law, and be ready to move on to the next stage called the religious stage. In the religious stage, human beings' highest duty is toward God as the infinite entity in the universe (Edwards, 1974:473). A religious person believes that objectivity can only be owned by the infinite creature (God), and human beings as finite entities do not have a capacity to be objective. Therefore, this stage allows each individual to commit and be responsible to what he/she believes as something that is true subjectively (faith to God). The important point in the religious level is not to get the answer to what we believe, but to be faithful and consistent to what we believe.

Opposing Kierkegard's point of view, Friedrich Wilhelm Nietzsche argues that to be authentic and to exist, an individual should omit the existence of God in his/her life (Tjaya, 2004:52). Instead, the absolute power in his/her life lies fully in his/her own hand. "I teach you the overman. Once the sin against God was the greatest sin; but God died, and these sinners died with him" (Hassan, 1992:52). This contradicts Kierkegaard's thought about human beings' relationship with God as the highest level of existentialism. According to Nietzsche, the essence of life is based on dualistic concepts; good and bad, strong and weak, brave and coward, etc. Only good, strong and brave human beings deserve to take control of the world. In other words, an existence of individual is achieved through a tight competition. "Brave is he who knows fear but conquers fear, who sees the abyss, but with 
pride" (Hassan, 1992:60). However, in some ways, Nietzsche shares the same point of view with Kierkegaard in terms of conquering fear by jumping into the abyss, but the different lie in how an individual can face his/her own fear. According to Kierkegaard, faith is the only key to jump to the abyss; while Nietzsche claims that bravery is the only key to conquer all fear. Although both Kierkegaard and Nietzsche have different points of view about facing fear, the main idea is the same: to be brave and to have a faith means to get ready to take a risk in life.

However, Nietzsche's existentialism abandons the role of individuals in their social relationships with society and their relationship with God subjectively. This paper will discuss how individuals can be identified as authentic and exist based on their relationship with God using the subjective truth analysis and the three stages of existentialism proposed by Kierkegaard. The illustration will draw from Indiana in the film Indiana Jones and the Last Crusade by identifying his stages which started from the young Indiana who believes that the museum is the right place to keep artifacts without any understanding of what Indiana believes. Kierkegaard identifies this stage as aesthetic. Then, the ethic stage requires Indiana to believe that finding facts is the only responsibility for archeologists. Finally, it is completed by the religious stage that requires Indiana to believe in something beyond facts, which is called truth to the absoluteness (God). Thus, this analysis can only be accomplished by using Kierkegaard's point of view about existentialism because Kierkegaard's thought provides a more complex analysis by not putting any limitations on human beings as individuals to make choices for their life.

\section{METHODOLOGY}

This research uses Indiana Jones and the Last Crusade movie, directed by Stephen Spielberg, as the instrument on account of the fact that this film is capable of illustrating the stages of existence that each individual goes through based on Kierkegaard's concept. My interest in conducting the research began from an interest in philosophy, especially existentialism. Therefore, I started to collect some books and materials that are relevant to existentialism, and read those materials for almost six months before conducting the research up to the present. Reading so many existentialists' thoughts such as Sartre's, Nietzsche's and Kierkegaard's, drawn my attention further to Kierkegaard because among other existentialists, Kierkegaard's concept sounds more optimistic and can depict how human beings deal with their life wisely. Meanwhile, my decision to use a film as an instrument came up while I was joining a film studies class in which at that time, Indiana Jones and the Last Crusade was examined. Watching the movie, I felt that Indiana is the right person to illustrate Kierkegaard's existentialism concept. However, before finally deciding to use Indiana Jones and the Last Crusade as the research instrument, I watched the other movie of Indiana, entitled Indiana Jones and Raiders of the Lost Ark. 
Although Raiders of the Lost Ark has several similarities to Indiana Jones and the Last Crusade, Raiders and the Lost Ark unfortunately failed to illustrate individual existence, and it lacks existentialism elements which I tried to focus in the research. Therefore, I finally decided to choose Indiana Jones and the Last Crusade as the research instrument.

The research is conducted by using the qualitative method, which does not involve any measurements or statistics. I specifically use a phenomenological research in conducting the research. The phenomenological method is a way of describing and analyzing one's own thought, feeling, and perception. To illustrate, in this research, I investigate Indiana's experience of emotion such as despair, anger, or cognitive processes like making a decision. The investigation is done by observing Indiana's stages of mind through examining the plot of the story, dialogues, facial expressions and Indiana's relationship with the other characters in the movie. The plot of the story required me to know how the story is built, and it may be helpful to know every character's background of their action-reaction for doing something, especially Indiana's action. Dialogues and facial expressions required me to know what Indiana feels under such circumstances in the movie, whether he shows his anger, despair, doubtful, fear, or other feelings. Meanwhile, Indiana's relationship with the other characters required me to know how influential the other characters are in building Indiana's faith and subjectivity as ways to exist. In brief, those elements will be used in the phenomenological method. Thus, using audiovisual tools like film is very helpful for me to do a comprehensive investigation toward Indiana because I can play and pause the movie for every scene that indicates Indiana's cognitive process to discover his authenticity. These scenes, then, were captured and included in the research as the supporting evidences before being integrated into Kierkegaard's existentialism concept.

The other reason why I finally nominated Indiana Jones and the Last Crusade as the research instrument is based on critical reviews written by several critics who stated that this movie gives a fresh air in action and science fiction movie genres. India Jones and the Last Crusade does not only expose a combat between a protagonist and an antagonist, but it also depicts their 'fight' for fulfilling their spiritual needs. In addition, this movie also portrays a mythology of the Holy Grail and some holy places in Petra, Middle East. These depictions aim to awaken people that myths do really exist in the real world. In brief, Indiana Jones and the Last Crusade tries to complete what is missing in other action genre movies. For those reasons, I am interested in analyzing this movie by using Kierkegaard's existentialism thought.

\section{ANALYSIS}

INDIANA'S EXPERIENCE OF DESPAIR AS A DETERMINANT OF SHAPING INDIANA'S SUBJECTIVETRUTH

Indiana Jones and the Last Crusade, a film directed by Stephen Spielberg that was 
released in 1989 by Paramount Pictures and Lucasfilm, tells about the adventure of Indiana and his father discovering a cup of Christ (the Holy Grail) that was used by Jesus in the last supper. To produce this movie, it took five years long, and it spent $\$ 48,000,000$ for its production cost. However, this movie gained its profit up to $\$ 474,171,806$ from all over the world. Actually, Indiana Jones and the Last Crusade is the third movie of Indiana Jones series after Raiders of the Lost Ark and Indiana Jones and the Temple of Doom. According to Caryn James in New York Times, Indiana Jones and the Last Crusade drew more attention than the previous Indiana Jones movies (www.movieweb.com). Indiana Jones and the Last Crusade mostly depicts Indiana's struggle to discover his subjectivity, to experience despairs and to pass through three stages of existentialism (aesthetic, ethical and religious stages) in order to determine Indiana's existence as authentic individual based on Soren Aabye Kierkegaard's thought.

The story was started by the emergence of young Indiana as a scout who was exploring Utah Mountain. Young Indiana coincidentally caught the treasure hunters who were digging up inside the cave and finally discovered the Cross of Coronado. The Cross of Coronado was the most valuable artifact which was used to crucify Jesus, and it had been the target for many archeologists and antique lovers. However, young Indiana whose father was archeologist believed that archeological artifacts should not be owned personally, but it should be kept in a museum to preserve cultural and historical heritage. According to Indiana, what the treasure hunters done toward the Cross of Coronado was totally unacceptable, so Indiana intended to steal the Cross of Coronado from the hand of treasure hunters and handed it to museum. Unfortunately, the treasure hunters knew what Indiana did, so they run chasing Indiana to get the Cross of Coronado back.

Based on the first scene of the movie, Young Indiana's comprehension of artifacts' proprietary right (the Holy Grail) was objective because he did not have any conscious knowledge about what he believed. Indiana did not really understand the reason why he believed that artifacts should be kept in museum because he did not base his concept of artifact's proprietary on his own comprehension subjectively. Instead, Little Indiana was objective (part of the crowd). Indiana's father, the professor of archeology, Dr. Henry Jones should be the reason why young Indiana possessed such belief because the first people who was met by Indiana after his successful runaway from the treasure hunters was his father. Indiana wanted his father to compliment Indiana's heroic action of saving the artifact because since Indiana was just a little boy, his father never told him what to do and never really 'care' for Indiana. According to Dr. Henry Jones, it was because he did not want to disturb Indiana's privacy. In other word, Indiana wanted to draw his father attention for saving the Cross of Coronado. Moreover, as Indiana grew up, Indiana was to be the professor of archeology like his father. It proved how big the influence of Indiana's father to Indiana so that Indiana set his father as the role model for Indiana's life. It shows that Indiana's reason for believing artifact archeology did not come from 
Indiana himself, but it came from the outside factor. Hence, it is called objective truth

Then, the story moves to the time when Indiana had been the professor of archeology who was teaching his students about how to be professional archeologist. Indiana explained to his students that archeologist was a study of discovering historical artifacts based on facts provided through research studies done in the library. In his explanation, Indiana stated that archeologist did not believe in mythology, lost cities, exotic travel and digging up the world. Neither did they believe in following maps to buried treasure. Therefore, when Indiana was asked by Dr. Donovan, antiques lover to help him discovering the cup of Christ used in the last supper (the Holy Grail), Indiana rejected it because according to Indiana, the Holy Grail was only a myth that the truth cannot be proved. At this point, Indiana's point of view to the Holy Grail was limited by his ideology as archeologist who was responsible to find the facts rather than truth. Indiana did not believe in the existence of the Holy Grail because it did not have any clear clues to be followed even though Donovan had shown Indiana incomplete sandstone tablet which had information about the place of the Holy Grail. However, Indiana thought the information written in the sandstone tablet was vague because it talked about unknown dessert, mountain and canyon which were difficult for archeologist like Indiana to start the discovery. Therefore, Indiana finally rejected Donovan's offer and said to Donovan that he met the wrong Jones. If it is myth that Donovan looked for, so his father, Dr. Henry Jones could be the right person to be met. However, Donovan said that Dr. Henry Jones had lost, and he could not meet him either. Knowing the fact that Indiana's father was lost, Indiana went to his father house to make sure that what Donovan said was not true. Actually, Indiana's rejection to Donovan's offer shows that Indiana's point of view is still controlled by the crowd. Indiana's understanding of archeology was comprehended based on others' point of view, not his, and this is called by Kierkegaard as objective truth. Indeed, individual who is still in his objectivity cannot be defined as authentic individual.

Hence forth, after getting the information about the lost of his father from Donovan, Indiana came to his father house and found that his father was not there. It surprised Indiana because at the same time Indiana was sent his father diary contained of his entire life research of the Holy Grail. It drew some questions to Indiana about the reason why his father sent the diary to Indiana because as Indiana knew, this diary was very important for his father, and there must be someone out there really wanted the diary. Instead of giving the diary to the wrong person, Dr. Henry Jones kept it away safely by sending it to Indiana. At this point, Indiana had just realized that his father was getting involved in the discovery of the Grail, and it suddenly distracted Indiana's belief in the Grail. In this case, Indiana was in his despair of not willing to be oneself because Indiana was confused of whether he should believe in the myth of the Grail and got involved in the discovery or kept maintaining his ideology as archeologist for not believing in the myth of the Grail. Indiana's despair was depicted from his 
dialogue with Marcus (Dr. Henry Jones' close friend). "Marcus, do you believe the Grail actually exists?" (Indiana Jones and the Last Crusade, 00:23:26). Marcus answered, "The search of the cup of Christ is the search for the divine in all of us. But, if you want facts, Indy, I've none to give you" (Indiana Jones and the Last Crusade, 00:23:28). From the dialogue, it can be inferred that Indiana was still in his objectivity, but when he experienced despair by questioning the truth of the Holy Grail, Indiana started to realize that the Holy Grail was something more than just historical artifact. Indiana's experience of despair helped Indiana in making decision. Hence, Indiana decided to accept Donovan's offer to discover the Grail by completing the missing part of the sandstone tablet, so he went to Venice, Italy, accompanied by Marcus. According to Kierkegaard's existentialism thought, Indiana's decision shows that Indiana can keep the balancing of his infiniteness and finiteness as human being. It also shows that Indiana had just built his subjectivity to the Grail.

Arriving in Venice, Indiana and Marcus were picked up by Dr. Schneider, a woman who worked for Donovan. Indiana and Dr. Schneider worked together to find the missing part of the sandstone tablet which was located under the oldest library in Venice, where there laid the tomb of Sir Richard, and the missing part was there in his shield. Indiana had successfully completed the missing part of the sandstone tablet and found out the name of the place where the Holy Grail was kept through the shield; it was Alexandretta. However, Indiana's discovery of the missing part of the sandstone was known by the Brotherhood of Cruciform Sword that was responsible to keep the secret of the Holy Grail from greedy people who longed for immortality from the Grail. The Brotherhood fought Indiana because they thought that Indiana wanted the Grail for his personal interest. Nevertheless, Indiana told them that his purpose was only to find his father and save him from the Nazi by following the directions written in his father dairy. Actually, up to this point, Indiana did not really believe in the existence of the Holy Grail, but he was just interested in following the facts written in the dairy as the clues to discover the Holy Grail. Indiana's attitude toward the Holy Grail shows that Indiana's point of view was still influenced by the concept of archeology.

However, although Indiana's point of view was still influenced by the concept of archeology, it did not stop Indiana to discover his own subjectivity to the Holy Grail, and it was depicted through the scene after Indiana rescued his father and had successfully escaped from Nazi. In this scene, Indiana had a debate with his father in the intersection between Venice and Berlin. Dr. Henry Jones asked Indiana to go to Berlin because they needed the diary stolen by Donovan and Dr. Schneider, who both of them had betrayed Indiana. Donovan and Dr. Schneider needed the diary to lead them to the place where the Holy Grail was kept, and their purpose of discovering the Holy Grail was to fulfill their personal interest; becoming immortal. Meanwhile, Indiana forced his father to go to Venice because Marcus had the map that could help them to find the place where 
the Holy Grail was kept. Actually, before the diary was stolen by Dr. Schneider from Indiana, Indiana had already torn the map from the dairy and handed it to Marcus who had gone to Iskenderun to meet Sallah (Indiana's friend) in order to keep the map away from Nazi. However, Dr. Henry Jones opposed Indiana's argument and stated that the diary was more important than the map because it contained some clues that could help them passing through the three challenges of the Holy Grail (the Breath of God, the Word of God and the Path of God). From these two points of views, we can conclude that Indiana was still very objective in comprehending the discovery of the Holy Grail. Indiana thought that the discovery of the Holy Grail was just similar to the discovery of historical artifacts which required Indiana as archeologist to follow the map with the exact places to start and to finish the discovery. Indiana's point of view was still constructed by archeological thinking that was set collectively by the crowd. However, at the end of their debate, Indiana finally decided to follow what his father told him; they went to Berlin. Indiana's decision to go to Berlin was based on his consciousness that there was something more important in the dairy than just the map. Indeed, it shows Indiana's subjective truth that is built by his own point of view.

From the previous explanations, we may infer that Indiana's journey to discover his own subjectivity is not stable, but rather fluctuated, and it is always followed by experiencing despair as the balancing element in establishing subjectivity. However, Indiana's subjectivity had completely established when he had to face the three challenges of the Holy Grail. It was the time when Indiana had to put off his ideology as archeologist and be prepared to face the reality that could only be acquired by faith. This will be elaborated more in the next section of the three stages of existentialism (aesthetic, ethical, and religious) passed by Indiana based on Kierkegaard's thought.

\section{THREE STAGES OF EXISTENTIALISM (AESTHETIC, ETHICAL, RELIGIOUS) PASSED BY INDIANA}

According to Kierkegaard, aesthetic is the lowest stage of existentialism because it requires human beings to act spontaneously without any considerations to some established values in society. In other words, their aim is only to fulfill their libido and desire. In Indiana Jones and the Last Crusade, young Indiana represents an individual who is in the aesthetic stage because of his spontaneous action rescuing the Cross of Coronado from the treasure hunters. Young Indiana believed that archeological artifacts should be kept in museum and nobody could own them personally. However, young Indiana did not really understand about his belief of artifacts' proprietary right concept and the reason why he did believe in such concept. What young Indiana knew was just that the Cross of Coronado should be kept in museum. Therefore, young Indiana stole the Cross of Coronado and kept it away from the treasure hunters. However, Indiana's 
spontaneous action stealing the Cross of Coronado was not followed by his responsibility to carry on the risk caused by what he had done. It can be illustrated from the scene when Indiana had successfully rescued the Cross of Coronado and intended to give it to sheriff. Unexpectedly, when young Indiana wanted to give the Cross of Coronado to the Sheriff so that it can be kept in museum, the Sheriff was not on Indiana's side, but he picked the Cross of Coronado and gave it to the treasure hunters. Unfortunately, young Indiana could do nothing, and let the Cross of Coronado moved to the hand of irresponsible people. Indiana's inability to fight for what he believed showed that he was not responsible, and he was not ready for the risk caused by what he had done. If he was responsible, he would do something to defend what he believed to be right. In fact, young Indiana did nothing. That is why, young Indiana is considered as aesthetic individual. However, as Indiana grew up, his aesthetic values had continuously decreased, and it had been replaced by the ethical values of archeological concept.

Afterwards, ethical stage of Indiana was reached when Indiana was to be the professor of archeology. As Kierkegaard stated in his existentialism thought, ethical stage requires human beings to comprehend the world based on others' point of view (the crowd) because they act upon the values/rules set by society. In this case, Indiana's ethical stage was depicted when Indiana rejected Donovan's offer to discover the Grail by the reason that archeology did not follow myth and unknown places to discover artifacts. Moreover, according to Indiana, the Holy Grail did not really exist. The other scene depicted Indiana's ethical stage was at the time when Indiana was debating with his father about which ways they should go. In this scene, Indiana chose to go to Venice by the reason to get the map back from Marcus. Indiana believed that archeological artifacts discovery needed the map as guidelines. At this point, Indiana was still influenced by archeological concept about discovering archeological artifacts. Therefore, Dr. Henry Jones metaphorically slapped Indiana by stating that, "The quest of the Grail is not archeology. It's a race against evil". (Indiana Jones and the Last Crusade, 01:06:25). Dr. Henry Jones emphasized that if everybody assumed that the quest of the Grail was the quest of archeology, they actually did not believe in the Grail because what they looked for was only something that was seen and reachable (being immortal caused by the Grail) without really understanding what the Grail actually wanted them (human beings) to comprehend; illumination. That is why, Dr. Henry Jones stated that it was a race against evil. Obviously, it contradicted to Indiana's point of view about discovering the Grail which was still controlled by collective understanding. Therefore, it shows that Indiana was still in ethical stage. According to Kierkegaard, to be exist and authentic, individual should move to the religious stage in which the highest duty of human beings is toward God.

Indiana's religious stage was depicted when Indiana had successfully disengaged his objectivity as archeologist (ethical stage) and moved forward to his faith to the Absurdity (God). This stage could be seen from the scene when Indiana had to pass three 
challenges of the Holy Grail (the Breath of God, the Word of God, and the Path of God). Arriving in the place where the Holy Grail was kept (Alexandretta), Indiana, his father, Marcus and Sallah found Dr. Donovan and Dr. Schneider had arrived earlier before them (Indiana, his father, Marcus and Sallah). Before Dr. Donovan realized that Indiana was there hiding behind the rocks inside the cave, Dr. Donovan asked one of his men to go through the first challenge of the Holy Grail. However, in just only few seconds, his head was cut off by the two plates of iron wheel, and he was death immediately. After Indiana, Dr. Henry Jones and their friends were caught by Donovan's men from their hiding, Donovan summoned Indiana to get the Holy Grail by passing through the three challenges of the Holy Grail. At first, Indiana rejected because up to this point, Indiana still did not believe that the Grail was actually exist inside the cave. Responding Indiana's rejection, Donovan shot Dr. Henry Jones (Indiana's father) on his belly. Then, Donovan told Indiana that the cure of his father wound could only be healed from the Grail. "It's time to ask yourself what you believe?" (Indiana Jones and the Last Crusade, 01:42:54). To answer Donovan's question, Indiana finally decided to go passing through the three challenges of the Holy Grail by using his father diary as the clue. However, the clues in the dairy were not similar to the clues that archeologist usually dealt with. The clues were written implicitly, and it needed Indiana's faith to comprehend it.

Indiana's decision to discover the Grail by passing through the three challenges of the Holy Grail showed that Indiana's point of view had already changed. Indiana's point of view was no longer controlled by the crowd. Instead, Indiana acquired the Grail based on his own faith subjectively. At this point, Indiana's subjectivity had completely established by possessing faith on his own. According to Kierkegaard, faith is precisely the contradiction between the infinite passion of the individual's inwardness and the objective uncertainty (Kenny, 2006:329). In other words, faith means complete surrender to the uncertainty. Uncertainty is something that we cannot predict, such as our future or our death. Indiana did not know what was going to happen with him after passing through the three challenges of the Holy Grail because what he knew only believing in what he did. Speculating nothing for what we are going to do is the key point that differentiates religious stage with ethical stage. This was actually what Indiana did when he had to pass the first challenge called the Breath of God; by believing.

The first challenge of the Holy Grail called the Breath of God contained of the clue which stated that 'only the penitent man will pass'. Actually, Indiana did not know what it meant by 'only penitent man will pass', but he kept repeating the sentences all over again in order to comprehend the meaning. Surprisingly, Indiana knew exactly the answer to complete the sentence, "the penitent man is humble kneels before God", and it was directly followed by Indiana's movement to kneel while the two plates of iron wheel were ready to cut off Indiana's head. Indiana had successfully passed through the first challenge. The next challenge was the Word of God. The clue for the second challenge 
was 'only in the footsteps of God will he proceed'. This second challenge required Indiana to form the name of God by stepping correctly on every letter carved on top of the brick floor. After contemplating the answer of the clue given, Indiana finally found the name, it was Jehovah; God that Indiana believed in. Indiana made his first step by stepping on the letter ' $\mathrm{J}$ ' as 'Jehovah', but unfortunately, the brick floor was crashed, so Indiana almost felt down. The mistake was the name of God should be translated into Latin which was started by the ' $\mathrm{I}$ ' letter; Iehovah. Realizing his mistake, Indiana started again by stepping the ' $\mathrm{I}$ ' letter to form the name of God (Iehovah), and he passed it. Finally, the last challenge of the Holy Grail called the Path of God. The path of God was the most dangerous challenging because it required Indiana to cross the canyons without any bridge at all.

The clue of the last challenge was 'only in the leap from the lion's head will he prove his worth'. In this scene, Indiana should be able to cross the canyons, but at first, Indiana did not believe that he could pass the canyons without any bridge at all. At this point, Indiana experienced despair whether he should continue his journey of discovering the Holy Grail by surrendering his life or stopped the journey and went back to his father. However, Indiana finally decided to continue his journey by crossing the canyons. In this scene, Indiana completely surrendered his life by stepping on the canyon, and expected nothing, but believing in God. Surprisingly, when Indiana stepped his foot, there lied an unseen bridge connected the canyons so that Indiana could go crossing the canyons without dying. This scene depicted that Indiana's faith toward God had already established, and he proved his faith by the act of faith jumping into the abyss; crossing the canyons. Actually, the true bridge was not the unseen bridge, but Indiana's faith toward God was the bridge that connected him to the owner of the objective truth, God. If Indiana was still in his objectivity, Indiana would never want to face the uncertain things like the three challenges of the Holy Grail. Instead, he would prefer to fight Donovan and his men, then, saved his father. Therefore, the last challenge of the Holy Grail determines Indiana's existence as authentic individual because his highest duty is no longer toward collective values and norms in society, but toward God.

At the end of the movie, Indiana was finally met the Knight who had kept the Holy Grail for almost six hundred years. A story about the knight was the story that was used to be neglected by Indiana because he thought that it was only myth. However, the meeting of Indiana with the Knight had proved that Indiana's assumption about the story was not entirely true, so Indiana was quite surprised with the fact that there was human who had been living for almost six hundred years. Indiana's coming to the place where the Holy Grail kept was surprised the Knight too because Indiana was the only person who had successfully passed through the three challenges of the Holy Grail. In other words, Indiana had just vanquished the Knight keeper of the Holy Grail, so the Knight gave his sword to Indiana as a form of honor. However, Indiana did not want to accept the sword because his purpose of discovering the Holy Grail was to cure his father's wound. Actually, Indiana's 
decision for not accepting the sword given by the knight shows that Indiana has put off his objectivity as archeologist. If Indiana was still in his objectivity, he would take the sword as the historical artifact which would end in museum. However, Indiana did not do so because what important for him was saving his father's life by using the Grail. It was not the Grail that gave the cure, but Indiana's faith that God would cure his father through the Grail was the point of Indiana's existence. Therefore, when Indiana had to choose which Grail was actually used by Jesus in the last supper, Indiana chose the old one among the other golden Grails. Nevertheless, to prove that it was the right Grail, Indiana should test it by drinking the water using the Grail he picked. If it was the wrong Grail, Indiana would be died like what happened to Donovan. Donovan did not get the immortality from the Grail as what he dreamed of because he picked the wrong one. Indiana's action of testing the Grail shows that Indiana represents the Knight of Faith because he did not experience despair whether the Grail he picked was right or wrong, whether he would die or gain eternal life because at this point, Indiana's faith was vertically toward God. Fortunately, there was nothing happen after Indiana drinking the water by using the Grail. The knight said that Indiana had chosen the right one, and he chose wisely.

Soon after that, Indiana rushed back to his father with the Grail on his hand. However, before Indiana met his father, the Knight warned that the immortality caused by the Grail would disappear after the Great Seal, and the Holy Grail cannot be brought passing the Great Seal as well, or destruction might occur. Indiana understood the consequences, but he did not intend to bring the Grail passing the Great Seal because what he wanted to do just save his father's life. Hence, Indiana poured the water from the Grail to his father wound, and the wound was immediately cured without any traces. Indiana felt so relieved that finally his father was cured. After saving his father's life, the Grail was suddenly taken by Dr. Schneider. She wanted to own the Grail and carried it out from the place where it was kept. However, Indiana warned her that the Grail should not be carried out from its place, but Schneider would not listen to what Indiana said. Because of what Schneider had done, the cave was going to collapse, and destruction was about to begin. Furthermore, Schneider felt down and buried under the soil cracks when she was about to grasp the Grail. Meanwhile, Indiana, Dr. Henry Jones, Marcus and Sallah ran outside the cave before it was entirely collapsed. From this scene, we can infer that Dr. Schneider did not really believe in the Grail because she comprehended the Grail not more than just the prize and archeological artifacts that could give her immortality and glory. Meanwhile, Indiana and Dr. Henry Jones comprehended the Holy Grail as illumination that the immortality would never be gained by human beings as the finite entity, but human beings' commitment to keep their faith to God was the one that was immortal. Therefore, at this point, Indiana is officially nominated as the most authentic individual based on Kierkegaard's existentialism thought for having successfully passed through the three challenges of the Holy Grail. 


\section{CONCLUSION}

The purpose of this essay is to give readers further comprehension about existentialism thought by Soren Aabye Kierkegaard by applying the elements of existentialism to Indiana in the movie Indiana Jones and the Last Crusade. In this movie, Indiana represents an authentic individual based on existentialism elements proposed by Kierkegaard. It proves from Indiana's success of disengaging his objectivity as archeologist by believing in the existence of the cup of Christ (the Holy Grail). In pursuing his subjectivity as an individual, Indiana experienced tension of whether he should or should not believe in the Grail which is called as despair. Under this circumstance, Indiana's experience of despair proves that Indiana can balance his finiteness and infiniteness as human being and be ready to move on to the three stages of existentialism (aesthetic, ethical and religious) by maintaining his subjectivity. Furthermore, Indiana's experience of three stages of existentialism was clearly depicted from the entire plots of the movie, especially in the last scene of the movie (Indiana's success of passing through the three challenges of the Holy Grail) by examining the dialogues and character development of Indiana.

However, there are some other elements of existentialism thought by Kierkegaard which are still not discussed in the case of analyzing Indiana in the movie Indiana Jones and the Last Crusade, one of them is Existence Precedes Essence. Therefore, through this essay writing, I hope it will encourage other researcher to discover a new finding related to my analysis.

\section{BIBLIOGRAPHY}

Cooper, D.E. Existentialism. Second Edition. London: Blackwell. 1999.

Edwards, H.W. Backgrounds of American Literature. New York: Prentice-Hall. 1974.

Hassan. F. Berkenalan dengan Eksistensialisme. Jakarta: Pustaka Jaya. 1992.

James, C. Episode III: Return of the Nazis (or the Nazis strike back). Diunduh pada tanggal 14 Agustus 2011, dari http://www.movieweb.com/movie/indiana-jones-the-last-crusade/ REiihqWS005tlj. 2011.

Kenny, A. An Illustrated Brief History of Western Philosophy. London: Blackwell. 2006.

Kierkegaard. S. Concluding Unscientific Postscript to Philosophical Fragments. London: Princeton. 1992.

Roubiczek, P. Existentialism for and Against. London: Cambridge University Press. 1964.

Spielberg, S. (Director), Lucas G. \& Meyjes M. (Writer). Indiana Jones and the Last Crusade [Motion Pictures]. United States: Paramount Pictures. 1989.

Tjaya, T. H. Kierkegaard dan Pergulatan Menjadi Diri Sendiri. Jakarta: Kepustakaan Populer Gramedia. 2004. 